\title{
Pengembangan Aplikasi Berbasis Android Untuk Pengenalan Huruf Hijaiyah
}

\author{
Wawan Gunawan \\ Universitas Mercu Buana \\ e-mail: wawan.gunawan@mercubuana.ac.id
}

\begin{abstract}
Abstrak
Huruf Hijaiyah atau huruf arab digunakan untuk membaca Al-Quran oleh orang-orang muslim di seluruh dunia sejak zaman dahulu. Mempelajari huruf hijaiyah merupakan suatu langkah awal untuk membaca kitab suci Al-Qur'an. Untuk meningkatkan kemampuan membaca huruf hijaiyah pada anak sangat diperlukan pemilihan metode atau media pembelajaran yang tepat serta strategi yang baik, karena memiliki andil yang sangat besar dalam proses pembelajaran. Sistem android merupakan sistem operasi yang banyak diminati oleh masyarakat dunia, sehingga aplikasi pembelajaran yang akan dapat digunakan di mana saja dan kapan saja. Konten yang diperlukan oleh pengguna dapat diakses dengan mudah dan dilengkapi dengan fasilitas multimedia yang mampu menggabungkan antara teks, gambar, dan suara dalam satu device. Dalam media edukasi ini, penulis membuat aplikasi untuk mengenalkan huruf hijaiyah beserta suara cara pengucapanya, yang menarik agar anak usia dini tertarik belajar huruf hijaiyah. Aplikasi pembelajaran yang akan digunakan untuk usia 3 sampai 9 tahun ini berisi materi pembelajaran huruf hijaiyah sampai dengan latihan-latihan. Perancangan aplikasi pengenalan huruf hijaiyah ini dikembangkan dengan pemrograman berbasis objek yaitu menggunakan Construct 2 berbasis HTML 5 .
\end{abstract}

Kata Kunci: Huruf Hijaiyah, Android, Construct 2, SDLC, Anak Usia Dini.

\begin{abstract}
Hijaiyah letters are letters used in the Holy Qur'an which consists of 30 letters with several gifts. Learning hijaiyah letters is a first step to reading the Holy Qur'an. Learning the ability to read hijaiyah letters requires a good strategy, therefore choosing the right learning method or media and having a big contribution in improving the ability to read children's hijaiyah letters. Along with the development of mobile technology, especially the Android operating system that is in great demand by the world community, the information system is installed in mobile so that the use of the application can also be used anywhere and anytime. The content that the user has can be accessed easily. Equipped with multimedia facilities that can combine text, images and sound in one device. In this educational media, the author makes an application to introduce the letters hijaiyah along with the sound of the way to speak, which is interesting so that early childhood children are interested in learning hijaiyah letters. This educational application is an application of learning for early childhood starting from the age of 3 to 9 years which contains the subject matter of hijaiyah letters up to exercises. The design of this hijaiyah letter recognition application was developed with object-based programming using HTML 5-based Construct 2.
\end{abstract}

Keywords: Hijaiyah Letter, Android, Construc 2, SDLC, Early Childhood

\section{Pendahuluan}

Anak usia dini pada era sekarang ini dihadapkan pada banyak teknologi yang ada di lingkungan sekitar, diantaranya adalah handphone, televisi, dan komputer. Teknologi dan media akan menjadi alat yang efektif dalam pembelajaran jika digunakan secara tepat dan bijak. Aplikasi multimedia mampu menarik perhatian dan minat siswa dalam proses pembelajaran karena disajikan dalam bentuk gambar serta animasi, dibuktikan oleh $80 \%$ dari 26 responden menyetujui hal tersebut (Wijaya \& Devianto, 2019). 
Android adalah sistem operasi yang dikeluarkan oleh Google khususnya untuk smartphone dan tablet. Android juga mempunyai store dimana terdapat 1 miliar pengguna aktif. Berbicara tentang pemrograman tentunya tidak lepas dari Integrated Development Environment (IDE) yang bisa dipakai oleh para Developere (Imaduddin \& Permana, 2017), penggunaan Informasi dan Teknologi Komunikasi melahirkan suasana yang menyenangkan dalam sebuah pembelajaran, karena terdapat gambar, video dan suara yang muncul sehingga membuat anak-anak tidak cepat bosan dan dapat memacu pembelajaran pada anak usia dini.

Mempelajari huruf hijaiyah merupakan suatu langkah awal untuk membaca kitab suci Al-Qur'an. Strategi yang baik akan sangat diperlukan dalam kemampuan belajar membaca huruf hijaiyah, oleh karena itu pemilihan metode atau media pembelajaran yang tepat mempunyai andil besar dalam meningkatkan kemampuan membaca huruf hijaiyah anak. Aplikasi pembelajaran dapat dipasang di mobile sehingga penggunaannya dapat dilakukan di mana saja dan kapan saja tidak terbatas akan ruang dan waktu (Muyaroah \& Fajartia, 2017). Multimedia yang menggabungkan teks, gambar, dan audio dalam satu device merupakan konten yang dapat diakses dengan mudah dan sangat diperlukan oleh pengguna (Ellis, 2001), sehingga dapat mempermudah dalam mempelajari huruf hijaiyah.

\section{Metode Penelitian}

Metode penelitian yang akan digunakan dalam pembuatan aplikasi ini adalah metode System Development Life Cycle (SDLC) yang dilakukan berdasarkan 5 tahap yaitu:

a. Analisa kebutuhan software

Metode perancangan yang akan digunakan dalam aplikasi pengenalan huruf hijaiyah berbasis mobile ini adalah menggunakan Construct 2 berbasis HTML 5 dan Adobe Photoshop.

b. Desain sistem

Melakukan perancangan aplikasi tentang pengenalan huruf hijaiyah dan kebutuhan perancangan system yang akan dilakukan dengan menggunakan alur dan storyboard untuk menjalankan alur aplikasi c. Penulisan kode program

Pada tahap ini penulis melakukan koding pada program untuk membuat suatu alur dalam aplikasi tersebut.

d. Pengujian program

Pada tahapan ini, aplikasi yang telah siap digunakan akan diuji. Pengujian dilakukan secara langsung menggunakan smartphone/Tablet $P C$ berbasis android untuk mengetahui sejauh mana aplikasi ini akan bekerja secara baik dan benar.

e. Penerapan program dan pemeliharaan Penerapan program dilakukan setalah melewati tahap pengujian program dan menerapkannya kepada user atau pengguna tentang bagaimana tanggapan dari aplikasi tersebut.

\section{Hasil dan Pembahasan}

\subsection{Analisa Kebutuhan Aplikasi}

Peralatan pendukung merupakan hardware dan software yang digunakan untuk pembuatan aplikasi ini. Berikut adalah spesifikasinya:

\section{a. Hardware}

Tabel 1. Hardware

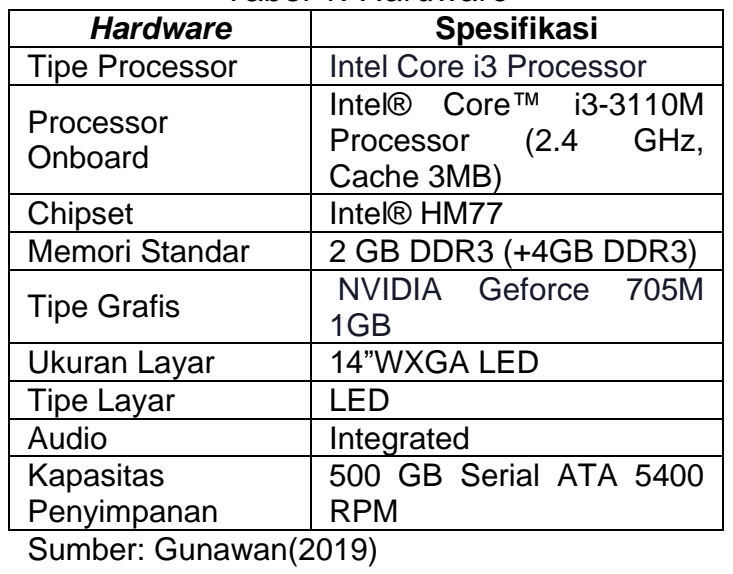

\section{b. Software}

Tabel 2. Software

\begin{tabular}{|l|l|}
\hline OS & $\begin{array}{l}\text { Microsoft Windows } 10 \\
\text { Ultimate (64bit) }\end{array}$ \\
\hline Game Engine & Construct 2 \\
\hline Editor Gambar & Adobe Photoshop \\
\hline UML & Draw.io \\
\hline APK Builder & Cocoon.io \\
\hline
\end{tabular}

Sumber: Gunawan(2019) 


\subsection{Testing}

\section{Black Box Testing}

Black box testing adalah pengujian yang dilakukan hanya berupa pengamatan atas hasil eksekusi melalui pengujian data dan pemeriksaan atas fungsional perangkat lunak (Ramadhan \& Utomo, 2014). Jadi dianalogikan seperti kita melihat suatu kotak hitam, kita hanya bisa melihat penampilan bagian luar saja, tanpa mengetahui yang tersimpan di dalam bungkus hitamnya. Sama halnya dengan pengujian black box, kita hanya mengevaluasi tampilan luar dari aplikasi dan fungsionalitas aplikasi tanpa mengetahui apa sesungguhnya yang terjadi dalam proses detilnya (hanya menegetahui input dan output).

Tabel.3 Pengujian Menu Utama

\begin{tabular}{|c|c|c|c|}
\hline $\begin{array}{c}\text { Data } \\
\text { masukan }\end{array}$ & Harapan & Pengamatan & Hasil \\
\hline $\begin{array}{c}\text { Tombol } \\
\text { Belajar }\end{array}$ & $\begin{array}{c}\text { Menampilkan } \\
\text { menu belajar }\end{array}$ & $\begin{array}{c}\text { Memilih menu } \\
\text { belajar }\end{array}$ & Tampil \\
\hline $\begin{array}{c}\text { Tombol } \\
\text { Latihan }\end{array}$ & $\begin{array}{c}\text { Menampilkan } \\
\text { menu latihan }\end{array}$ & $\begin{array}{c}\text { Memilih menu } \\
\text { latihan }\end{array}$ & Tampil \\
\hline $\begin{array}{c}\text { Tombol } \\
\text { Tentang }\end{array}$ & $\begin{array}{c}\text { Menampilkan } \\
\text { informasi }\end{array}$ & $\begin{array}{c}\text { Muncul papan } \\
\text { informasi }\end{array}$ & Tampil \\
\hline $\begin{array}{c}\text { Tombol } \\
\text { Sound }\end{array}$ & $\begin{array}{c}\text { Menyalakan } \\
\text { atau } \\
\text { mematikan } \\
\text { backsound }\end{array}$ & $\begin{array}{c}\text { Sound On } \\
\text { atau Off }\end{array}$ & Tampil \\
\hline Tombol \\
Exit & $\begin{array}{c}\text { Tekan } \\
\text { tombol X } \\
\text { pada } \\
\text { tampilan }\end{array}$ & Keluar aplikasi & Tampil \\
\hline
\end{tabular}

Sumber: Gunawan(2019)

Tabel.4 Pengujian Menu Belajar

\begin{tabular}{|c|c|c|c|}
\hline $\begin{array}{c}\text { Data } \\
\text { masukan }\end{array}$ & Harapan & Pengamatan & Hasil \\
\hline $\begin{array}{c}\text { Tombol } \\
\text { Belajar } \\
\text { Hijaiyah }\end{array}$ & $\begin{array}{c}\text { Menampilkan } \\
\text { huruf hijaiyah } \\
\text { salah satu } \\
\text { button huruf } \\
\text { dan keluar } \\
\text { suaranya }\end{array}$ & Tampil \\
\hline $\begin{array}{c}\text { Tombol } \\
\text { Belajar } \\
\text { Harokat }\end{array}$ & $\begin{array}{c}\text { Menampilkan } \\
\text { menu } \\
\text { harokat }\end{array}$ & $\begin{array}{c}\text { Memilih menu } \\
\text { harokat }\end{array}$ & Tampil \\
\hline $\begin{array}{c}\text { Tombol } \\
\text { Belajar } \\
\text { Tanwin }\end{array}$ & $\begin{array}{c}\text { Menampilkan } \\
\text { Menu tanwin }\end{array}$ & $\begin{array}{c}\text { Memilih menu } \\
\text { tanwin }\end{array}$ & Tampil \\
\hline $\begin{array}{c}\text { Tombol } \\
\text { back }\end{array}$ & $\begin{array}{c}\text { Kembali ke } \\
\text { menu } \\
\text { sebelumnya }\end{array}$ & $\begin{array}{c}\text { Menampikan } \\
\text { menu } \\
\text { sebelumnya }\end{array}$ & Tampil \\
\hline
\end{tabular}

Sumber: Gunawan(2019)
Tabel.5 Pengujian Menu Belajar Harokat

\begin{tabular}{|c|c|c|c|}
\hline $\begin{array}{c}\text { Data } \\
\text { masukan }\end{array}$ & Harapan & Pengamatan & Hasil \\
\hline $\begin{array}{c}\text { Tombol } \\
\text { Farokat }\end{array}$ & $\begin{array}{c}\text { Menampilkan } \\
\text { huruf hijaiyah } \\
\text { berharokat } \\
\text { fathah }\end{array}$ & $\begin{array}{c}\text { Menekan } \\
\text { salah satu } \\
\text { button huruf } \\
\text { dan keluar } \\
\text { suaranya }\end{array}$ & Tampil \\
\hline $\begin{array}{c}\text { Tombol } \\
\text { Harokat } \\
\text { Kasrah }\end{array}$ & $\begin{array}{c}\text { Menampilkan } \\
\text { Huruf } \\
\text { hijaiyah } \\
\text { berharokat } \\
\text { kasrah }\end{array}$ & $\begin{array}{c}\text { Menekan } \\
\text { salah satu } \\
\text { button huruf } \\
\text { dan keluar } \\
\text { suaranya }\end{array}$ & Tampil \\
\hline $\begin{array}{c}\text { Tombol } \\
\text { Harokat } \\
\text { Dhomah }\end{array}$ & $\begin{array}{c}\text { Menampilkan } \\
\text { hijaiyah } \\
\text { berharokat } \\
\text { dhomah }\end{array}$ & $\begin{array}{c}\text { Menekan } \\
\text { salah satu } \\
\text { button huruf } \\
\text { dan keluar } \\
\text { suaranya }\end{array}$ & Tampil \\
\hline $\begin{array}{c}\text { Kembali ke } \\
\text { menu }\end{array}$ & $\begin{array}{c}\text { Menampikan } \\
\text { menu } \\
\text { sack }\end{array}$ & $\begin{array}{c}\text { Thelumnya } \\
\text { sebelumnya }\end{array}$ & Tampil \\
\hline
\end{tabular}

Sumber: Gunawan(2019)

Tabel.6 Pengujian Menu Belajar Tanwin

\begin{tabular}{|c|c|c|c|}
\hline $\begin{array}{c}\text { Data } \\
\text { masukan }\end{array}$ & Harapan & Pengamatan & Hasil \\
\hline $\begin{array}{c}\text { Tanwin } \\
\text { Fathah }\end{array}$ & $\begin{array}{c}\text { Menampilkan } \\
\text { huruf hijaiyah } \\
\text { berharokat } \\
\text { tanwin fathah }\end{array}$ & $\begin{array}{c}\text { Menekan } \\
\text { salah satu } \\
\text { button huruf } \\
\text { dan keluar } \\
\text { suaranya }\end{array}$ & Tampil \\
\hline $\begin{array}{c}\text { Tombol } \\
\text { Tanwin }\end{array}$ & $\begin{array}{c}\text { Menampilkan } \\
\text { Karuf hijaiyah } \\
\text { berharokat } \\
\text { tanwin kasrah }\end{array}$ & $\begin{array}{c}\text { Menekan } \\
\text { salah satu } \\
\text { button huruf } \\
\text { dan keluar } \\
\text { suaranya }\end{array}$ & Tampil \\
\hline $\begin{array}{c}\text { Tombol } \\
\text { Tanwin }\end{array}$ & $\begin{array}{c}\text { Menampilkan } \\
\text { berharokat } \\
\text { Dhomah }\end{array}$ & $\begin{array}{c}\text { Menekan } \\
\text { salah satu } \\
\text { button huruf } \\
\text { dan keluar } \\
\text { suaranya }\end{array}$ & Tampil \\
\hline
\end{tabular}

Sumber: Gunawan(2019)

Tabel.7 Pengujian Menu Latihan

\begin{tabular}{|c|c|c|c|}
\hline $\begin{array}{c}\text { Data } \\
\text { masukan }\end{array}$ & Harapan & Pengamatan & Hasil \\
\hline $\begin{array}{l}\text { Tombol } \\
\text { Mulai } \\
\text { Latihan }\end{array}$ & $\begin{array}{c}\text { Menampilkan } \\
\text { Soal latihan } \\
\text { acak }\end{array}$ & $\begin{array}{c}\text { Menjawab } \\
\text { dengan } \\
\text { benar/salah. } \\
\text { Jika benar } \\
\text { lanjut ke soal } \\
\text { berikutnya dan } \\
\text { mendapatkan } \\
\text { score jika salah } \\
\text { menampilkan } \\
\text { score akhir dan } \\
\text { highscore }\end{array}$ & Tampil \\
\hline $\begin{array}{c}\text { Tombol } \\
\text { Play Again }\end{array}$ & $\begin{array}{l}\text { Menampilkan } \\
\text { soal kembali } \\
\text { secara acak }\end{array}$ & $\begin{array}{c}\text { Menjawab soal } \\
\text { lagi seperti } \\
\text { awal }\end{array}$ & Tampil \\
\hline $\begin{array}{c}\text { Tombol } \\
\text { Home }\end{array}$ & $\begin{array}{l}\text { Kembali ke } \\
\text { menu utama }\end{array}$ & $\begin{array}{c}\text { Menampilkan } \\
\text { menu utama }\end{array}$ & Tampil \\
\hline
\end{tabular}

Sumber: Gunawan(2019) 


\section{White Box Testing}

Secara umum hhite box testing merupakan jenis testing yang berkonsentrasi pada isi dari perangkat lunak (Janti, 2017). White Box testing adalah pengujian berdasarkan atas pengecekan terhadap detail perancangan, penggunaan struktur kontrol dari desain sistem secara prosedural untuk membagi pengujian ke dalam beberapa kasus pengujian yang dibuat dalam bentuk flowchart.

Pengujian tidak dilakukan terhadap seluruhan aplikasi utuh, tetapi dilakukan pada aplikasi yang dijalankan sebagai contoh pengujian.

a. Pengujian White box menu belajar hijaiyah

Alur dari menu belajar hijaiyah yaitu apabila kita mengklik atau menekan salah satu button huruf hijaiyah makan akan muncul suara bacanya.

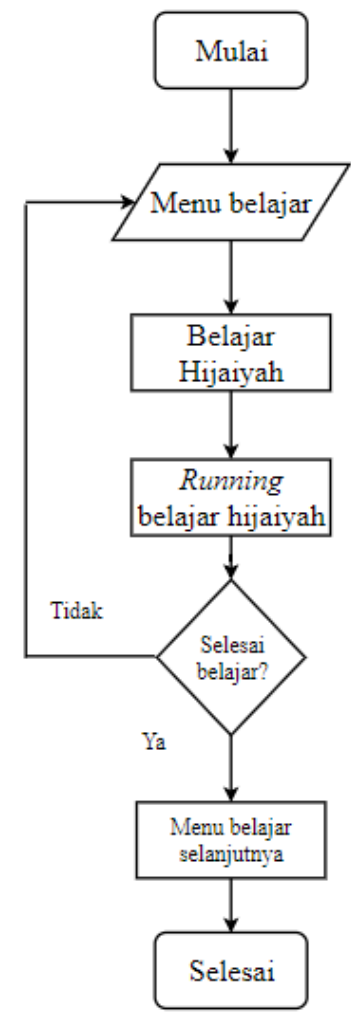

Sumber: Gunawan(2019)

Gambar 1.Bagan alir menu belajar hijaiyah

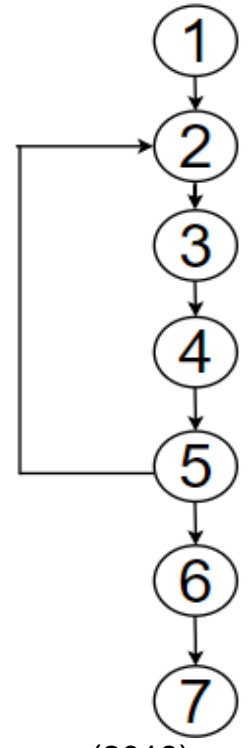

Sumber: Gunawan(2019)

Gambar 2. Grafik alir menu belajar hijaiyah

Kompleksitas siklomatis dari gambar 2 dapat diperoleh dengan rumus

$$
\mathrm{V}(\mathrm{G})=(\mathrm{E}-\mathrm{N})+2
$$

$V(G)=$ Jumlah Region

$\mathrm{E}=$ Jumlah sisi ditentukan gambar panah

$\mathrm{N}$ = Jumlah simpul grafik alir ditentukan gambar lingkaran sehingga didapat:

$\mathrm{V}(\mathrm{G})=(7-7)+2$

$$
=2
$$

$\mathrm{V}(\mathrm{G})<10 \rightarrow$ memenuhi kekompleksitasi siklomatisnya.

Data set yang dihasilkan dari jalur independen adalah sebagai berikut:

a) $1-2-3-4-5-6-7$

b) $1-2-3-4-5-2$

b. Pengujian White box menu latihan Alur dari menu latihan yaitu menjawab dengan benar/salah lalu akan muncul popup jawaban. Jika benar lanjut ke soal berikutnya jika salah mengulang kembali soal tersebut. 


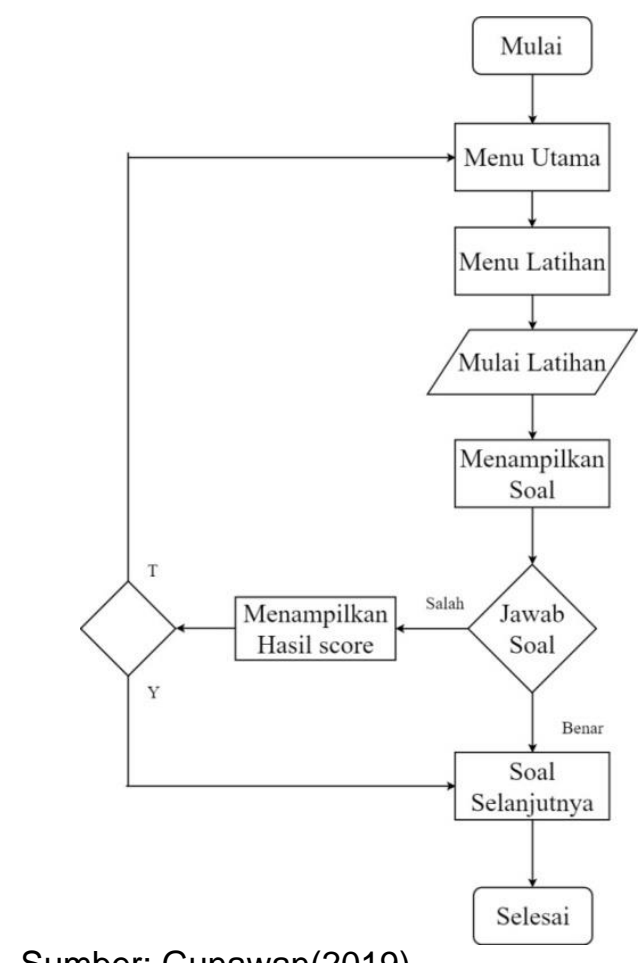

Sumber: Gunawan(2019)

Gambar 3. Bagan alir menu latihan

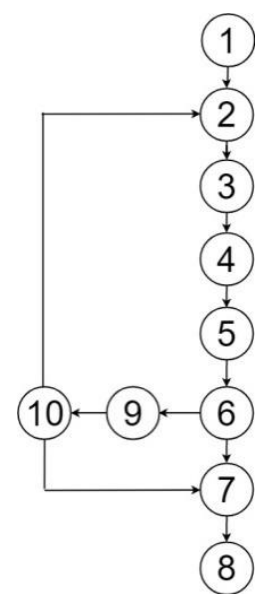

Sumber: Gunawan(2019)

Gambar 4. Grafik alir menu latihan

Kompleksitas siklomatis dari gambar 4 dapat diperoleh dengan rumus

$$
V(G)=(E-N)+2
$$

$\mathrm{V}(\mathrm{G})=$ Jumlah Region

$\mathrm{E} \quad=$ Jumlah sisi ditentukan gambar panah

$\mathrm{N}=$ Jumlah simpul grafik alir ditentukan gambar lingkaran sehingga didapat:

$\mathrm{V}(\mathrm{G})=(11-10)+2$

$$
=3
$$

$\mathrm{V}(\mathrm{G})<10 \rightarrow$ memenuhi kekompleksitasi siklomatisnya.

Data set yang dihasilkan dari jalur independen adalah sebagai berikut:

a) $1-2-3-4-5-6-9-10-7-8$

b) $1-2-3-4-5-6-9-10-2$

c) $1-2-3-4-5-6-7-8$

\subsection{Implementasi}

Setelah pembuatan suatu aplikasi selesai maka tahap selanjutnya adalah implementasi aplikasi. Implementasi merupakan tahap peletakan sistem yang baru dikembangkan sehingga nantinya dapat dioperasikan sesuai dengan harapan. Implementasi sistem merupakan kelanjutan dari pembuatan dan pemasangan sistem yang akan digunakan sesuai dengan desain yang telah direncanakan.

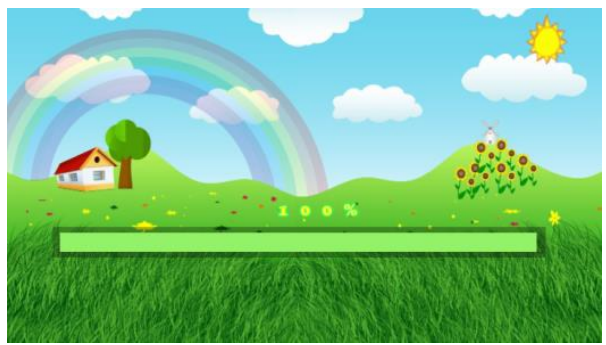

Sumber: Gunawan(2019)

Gambar 5. Tampilan loading

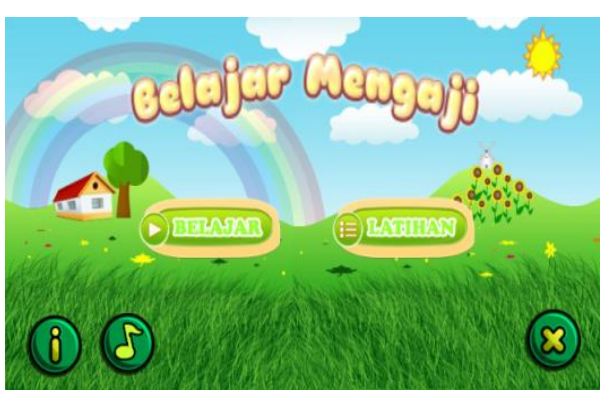

Sumber: Gunawan(2019)

Gambar 6. Tampilan Menu Utama

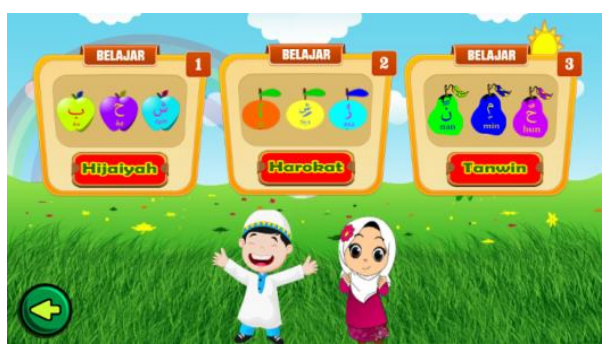

Sumber: Gunawan(2019)

Gambar 7. Tampilan Menu Belajar 


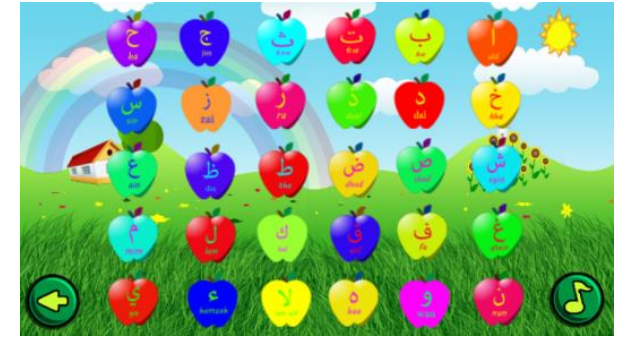

Sumber: Gunawan(2019)

Gambar 8. Tampilan belajar hijaiyah

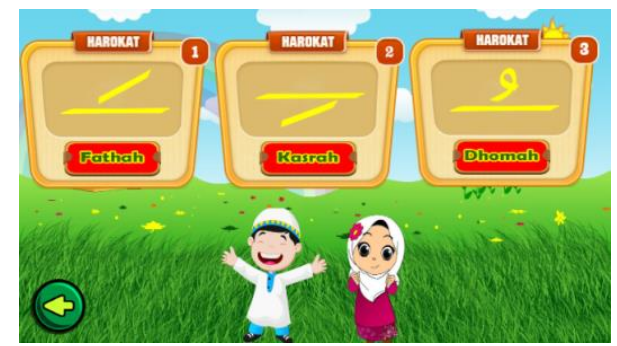

Sumber: Gunawan(2019)

Gambar 9. Tampilan belajar harokat

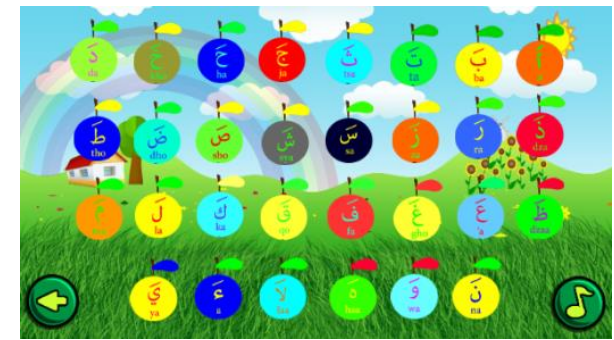

Sumber: Gunawan(2019)

Gambar 10. Tampilan harokat fathah

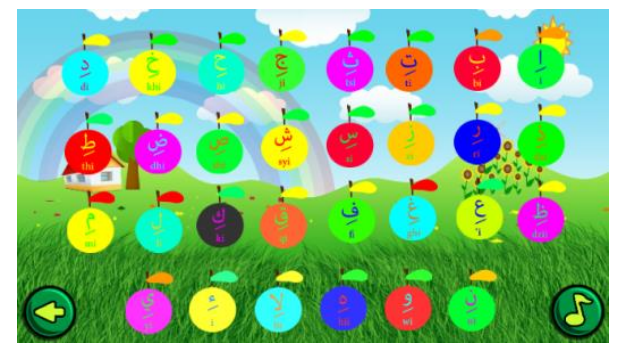

Sumber: Gunawan(2019)

Gambar 11. Tampilan harokat kasroh

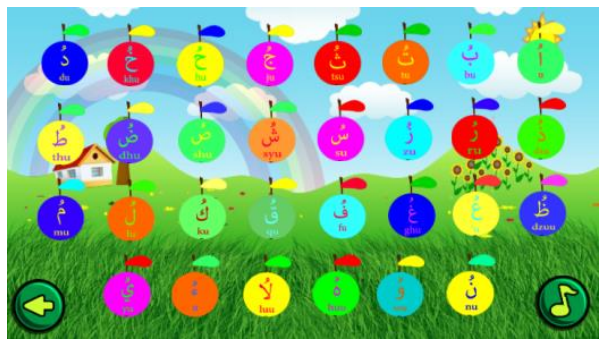

Sumber: Gunawan(2019)

Gambar 12. Tampilan harokat dhomah

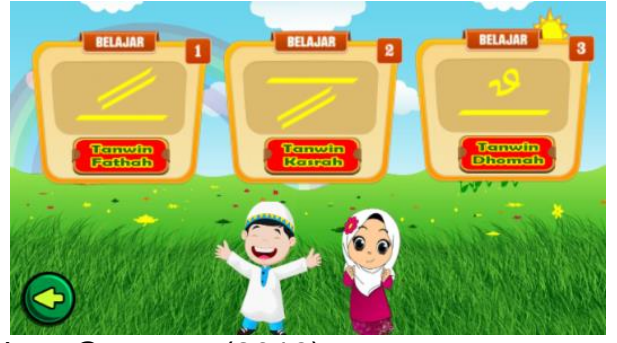

Sumber: Gunawan(2019)

Gambar 13. Tampilan belajar tanwin

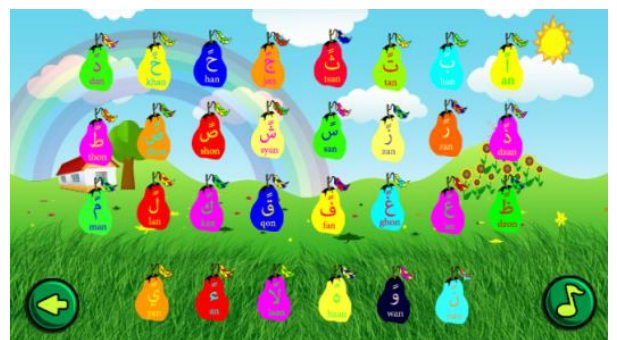

Sumber: Gunawan(2019)

Gambar 14. Tampilan tanwin fathah

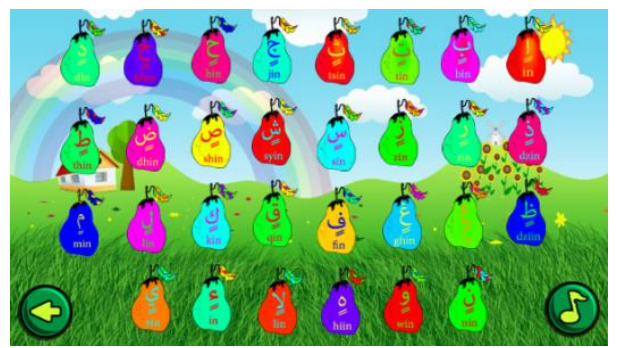

Sumber: Gunawan(2019)

Gambar 15. Tampilan tanwin kasrah

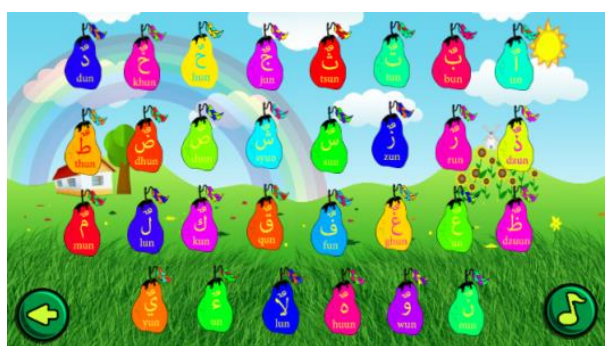

Sumber: Gunawan(2019)

Gambar 16. Tampilan tanwin dhomah

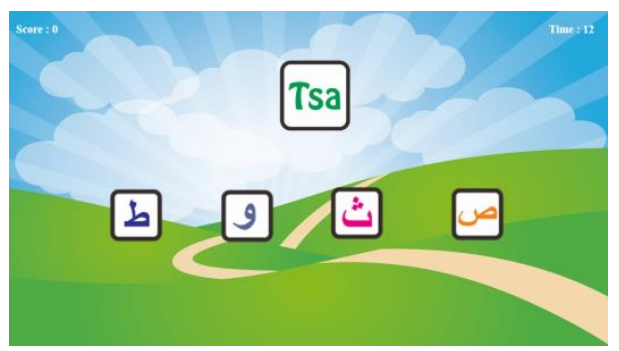

Sumber: Gunawan(2019)

Gambar 17. Tampilan latihan 


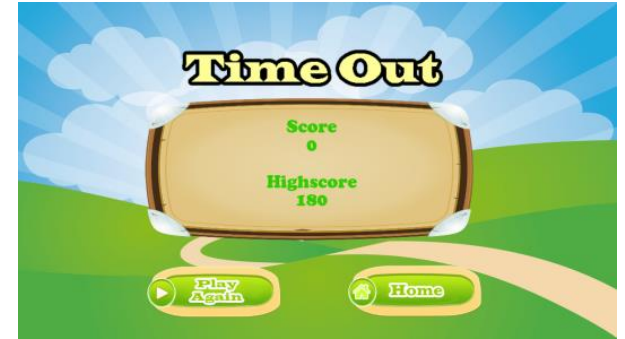

Sumber: Gunawan(2019)

Gambar 18. Tampilan timeout

\subsection{Verifikasi}

\section{a. Uji Fungsionalitas}

Tabel.8 Pengujian pada Beberapa versi Android

\begin{tabular}{|c|c|c|c|c|c|}
\hline Smartphone & Size & RAM & $\begin{array}{c}\text { Sistem } \\
\text { Operasi }\end{array}$ & Hasil & Hasil \\
\hline $\begin{array}{c}\text { Xiaomi } \\
\text { Redmi 5 Plus }\end{array}$ & $\begin{array}{c}5,7 \\
\text { inci }\end{array}$ & $4 \mathrm{~GB}$ & Nougat & Valid & Bagus \\
\hline $\begin{array}{c}\text { Xiaomi } \\
\text { Redmi Note } \\
3\end{array}$ & $\begin{array}{c}5,5 \\
\text { inci }\end{array}$ & $3 \mathrm{~GB}$ & Lollipop & Valid & Bagus \\
\hline $\begin{array}{c}\text { Oppo F7 } \\
\text { inci }\end{array}$ & $4 \mathrm{~GB}$ & Nougat & Valid & Bagus \\
\hline $\begin{array}{c}\text { Oppo a39 } \\
\text { inci }\end{array}$ & $3 \mathrm{~GB}$ & Lollipop & Valid & Bagus \\
\hline $\begin{array}{c}\text { Xiaomi } \\
\text { Redmi 3 pro }\end{array}$ & $\begin{array}{c}5 \\
\text { inci }\end{array}$ & $2 \mathrm{~GB}$ & Lollipop & Valid & Bagus \\
\hline
\end{tabular}

Sumber: Gunawan(2019)

b. Uji Materi Pembelajaran

Hasil kuisioner untuk anak usia 3 - 9 tahun dengan kriteria penilaian seperti pada tabel 9.

Tabel.9 Penjelasan Kategori Penilaian

\begin{tabular}{|c|l|}
\hline Kode & \multicolumn{1}{|c|}{ Keterangan } \\
\hline A & Kejelasan bahasa yang digunakan \\
\hline B & Tidak ada kata yang menyimpang \\
\hline C & Soal sesuai dengan materi \\
\hline D & Memahami materi pembelajaran \\
\hline E & Isi materi sesuai indikator \\
\hline F & Contoh-contoh latihan jelas \\
\hline G & Bahasa yang digunakan mudah dipahami \\
\hline H & $\begin{array}{l}\text { Soal yang diberikan sesuai dengan } \\
\text { kemampuan }\end{array}$ \\
\hline I & $\begin{array}{l}\text { Soal yang diberikan sesuai dengan } \\
\text { indikator pelajaran }\end{array}$ \\
\hline
\end{tabular}

Sumber: Gunawan(2019)

Hasil yang diperoleh dari penyebaran kuisioner tersebut adalah sebanyak 95\% sangat suka dengan aplikasi pengenalan huruf hijaiyah ini dengan ditunjukkan pada gambar 19.

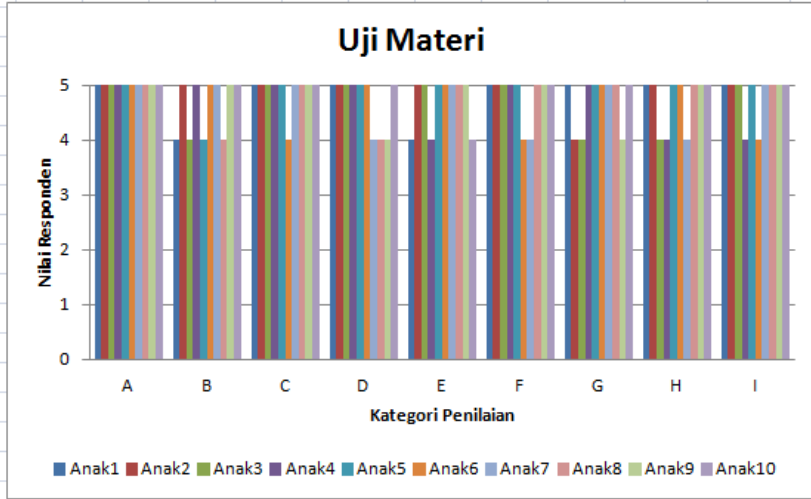

Sumber: Gunawan(2019)

Gambar 19. Penilaian Uji Materi pembelajaran

c. Uji Media Pembelajaran

Pengujian ini dilakukan guna mengetahui apakah desain yang dibuat, gambar yang digunakan, suara yang dipakai, huruf hijaiyah yang digunakan, maupun aspek pemrograman sesuai dengan konsep multimedia. Hasil dari kuisioner penilaian ini memberikan nilai $92,28 \%$ yang dapat diartikan sangat sesuai dengan kebutuhan.

\section{Kesimpulan}

Aplikasi pembelajaran diharapkan dapat menjadi media pembelajaran dalam mengenal huruf hijaiyah bagi anak-anak. Uraian di atas dapat disimpulkan bahwa aplikasi yang dibuat dapat membantu pengguna dalam mengetahui bentuk huruf hijaiyah serta pelafalannya sebagai dasar mempelajari atau membaca Al-Quran. Selain itu terdapat latihan soal untuk mengukur pemahaman pengguna aplikasi terhadap huruf hijaiyah. Aplikasi ini bisa dijalankan hanya untuk versi android versi 4.0 (Jelly Bean) keatas. Sebanyak 92,28\% memberikan penilaian bahwa aplikasi ini sangat sesuai dengan kebutuhan, namun aplikasi ini belum mendukung dalam mengakses konten dan berkomunikasi dengan penutur asli atau pengguna lain untuk mendukung pembelajaran (Ratnasari \& Haji, 2018).

\section{Referensi}

Efendi, R., Purwandari, E. P., \& Aziz, M. A. (2015). Aplikasi Pengenalan Huruf Hijaiyah Berbasis Marker Augmented Reality Pada Platform Android. Pseudocode. 
Ellis, T. J. (2001). Multimedia Enhanced Educational Products as a Tool to Promote Critical Thinking in Adult Students. Journal of Educational Multimedia and Hypermedia, 10(2), 107-123.

Imaduddin, A., \& Permana, S. (2017). Dicoding: Menjadi Android Developer Excpert. Bandung: Presentologics.

Janti, S. (2017). Animasi Edukasi Interaktif Tes Kemampuan Konsentrasi dengan Permainan Tebak Warna. Jurnal Teknik Komputer AMIK BSI, ISSN. 2442-2436, III(1), 106-113.

Muyaroah, S., \& Fajartia, M. (2017). Pengembangan Media Pembelajaran Berbasis Android dengan menggunakan Aplikasi Adobe Flash CS 6 pada Mata Pelajaran Biologi. Innovative Journal of Curriculum and Educational Technology (IJCET), pISSN 2252-7125, e-ISSN 25024558, 6(2), 79-83.
Ramadhan, T., \& Utomo, V. (2014). Rancang Bangun Aplikasi Mobile Untuk Notifikasi Jadwal Kuliah Berbasis Android (Studi Kasus: Stmik Provisi Semarang). Jurnal Teknologi Informasi Dan Komunikasi, 47-55.

Ratnasari, A., \& Haji, W. H. (2018). Developing Interface Design of Interactive Multimedia for Learning English in Senior High School. International Journal of Scientific Research in Computer Science, Engineering and Information Technology (IJSRCSEIT), ISSN: 2456-3307, 3(6), 317-323.

Wijaya, H. D., \& Devianto, Y. (2019). Application of Multimedia in Basic English Vocabulary Learning with the ADDIE Method. International Journal of Computer Techniques (IJCT), ISSN :2394-2231, 6(1), 5763. 